\title{
Myth Conceptions of Academic Work
}

\section{IAN C. JOHNSTON*}

\section{ABSTRACT}

The creation of the new university-colleges in British Columbia provides an opportunity for a reassessment of the professor's workload. How relevant are research and publication to the quality of undergraduate instruction? Universities have traditionally maintained that such research and publication are essential to excellent teaching. However, research studies for many years have consistently revealed that such a claim has no apparent basis in fact, and a number of other commentators have complained about the deleterious effect of research and publication on instruction. Thus, in the new university-colleges the instructors' workloads should not be based upon the models common in universities.

\section{RÉSUMÉ}

La création de nouveaux collèges universitaires en Colombie-Britannique nous donne l'occasion de réévaluer la charge de travail des professeurs d'université. Jusqu'à quel point la recherche et les publications sont-elles nécessaires à un enseignement universitaire de premier cycle? De tous temps, les universités ont maintenu que ces activités étaient essentielles à un enseignement de grande qualité. Pourtant, des études menées ces dernières années ont constamment montré que ces arguments n'étaient pas fondés dans les faits tandis que d'autres observateurs se plaignaient des effets négatifs de la recherche sur la qualité de l'enseignement. La charge de travail des professeurs des nouveaux collèges universitaires de Colombie-Britannique ne devrait donc pas prendre en compte les modèles existants dans les universités.

The recent transformation of the university-transfer curriculum in three community colleges in British Columbia (in Malaspina College in Nanaimo, Okanagan College in Vernon, and Cariboo College in Kamloops) from

* Malaspina College, Nanaimo, B.C 
two-year to four-year degree programmes has in the past few months rekindled the old debate about the appropriate relationship between academic research, publication, and teaching. Traditionally, faculty in these community colleges have seen teaching as their main responsibility, and, although each institution promotes professional development, there has been no obligation for instructors to conduct original research or to publish. Now, however, the addition of upper-division courses and the presence of the sponsoring universities in discussions about hiring and curriculum planning are placing considerable pressure on these colleges to alter their customary priorities, so that faculty teaching in the upper-division programmes organize their working lives more along the same lines as the university professor, with significantly more time devoted to research and publication and considerably less to teaching. This development has initiated some important and sometimes contumacious discussions about the most appropriate role for the instructor of undergraduates, and the arguments will presumably continue for some time until an agreement is reached and codified in a new contract. Clearly the issue is crucial to the colleges, for its resolution will determine whether these new four-year programmes become an important and long-overdue reform in undergraduate education or whether they will simply perpetuate the erroneous working principle which, more than any other single organizing factor, creates serious problems for the undergraduate programme in our universities.

On the relationship between academic research, publishing, and instruction, the official university stance has been clear and firm for many years. Article 1 in the "Preamble Statement on Academic Appointments and Tenure" in the CAUT Handbook (1979) declares: "The essential functions of a university are the pursuit and dissemination of knowledge and understanding, through research and teaching" (p. 8). And the relationship between the two is equally unambiguous in the CAUT recommendations to the federal and provincial governments (1987): "CAUT firmly believes that the teaching and research functions of the university should not normally be separated. Research informs the teaching process within the university and keeps it current. This is true both at the undergraduate and graduate levels" (p. 14). Moreover, research, for all practical purposes, almost invariably requires publication of articles in academic journals, because, in the words of Jencks and Riesman (1969), "Those who do not publish usually feel they have not learned anything worth communicating to adults. This means that they have not learned much worth communicating to the young either." And so one arrives at the orthodox university view: regular research and frequent publication are essential to good 
undergraduate instruction because they keep the professors up to date. Those who do not publish are not up to date and are, therefore, unsatisfactory teachers.

So deeply rooted is this principle, that it informs most of the relationship between universities and those colleges now offering upper-division courses. University advisors tell prospective students that programmes are better at the university because college faculty are not required to carry out research. And university departments involved with hiring faculty for the colleges usually insist upon a record of publications and a continuing commitment to research, on the ground that without research and publication the instructor will not be competent. The assumption clearly is that if one takes care of the research qualification, research activity, and publication, then one has done all that is necessary to promote good instruction.

It takes no great familiarity with doctoral programmes or with the present state of academic research and publication to recognize the enormously specialized work these require. So much so, in fact, that the immediate connections between those activities and the demands of instructing undergraduates are often by no means quite so obvious as the orthodox assertions claim. Given this discrepancy, one is not surprised to discover the chorus of counter-assertions, lamenting the deleterious effects on the undergraduate programme of the commitment to research and publication. This phenomenon is nothing new, of course, but the extraordinary growth in the past thirty years (at least) of the modern North American university as, among other things, a very specialized research facility has given a new edge to the complaints. In the words of Clark Kerr (1963), perhaps the best known defender of the "multiversity":

The reasons for the general deterioration of undergraduate teaching are several. Teaching loads and student contact hours have been reduced. Faculty members are more frequently on leave or temporarily away from campus. More of the instruction falls to teachers who are not members of the regular faculty...There seems to be a "point of no return" after which research, consulting, graduate instruction become so absorbing that faculty efforts can no longer be concentrated in undergraduate instruction as they once were. This process has been going on for a long time: federal research funds have intensified it. As a consequence, undergraduate education is more likely to be acceptable than outstanding; educational policy from the undergraduate point of 
view is largely neglected. How to escape the cruel paradox that a superior faculty results in an inferior concern for undergraduate teaching is one of our more pressing problems. (p. 65)

Kerr's words appeared more than twenty-five years ago. To judge from a number of recent books and articles on the same subject, the problem has grown much more acute. For Paul Von Blum (1986), a teacher for many years in the University of California, Kerr's "cruel paradox" has become "one of the most brutal ironies of university life...[the] recognition that to develop a reputation as an excellent teacher is professionally disadvantageous and dangerous" (p. 51). Von Blum sees this development as a natural consequence of a system which, whatever the official policies may be, has, in practice, failed to effect any creative union between teaching and research and which has constantly over-valued very specialized research and publication as the sole means for professional advancement. The president of Mount Saint Vincent University in Halifax, E. Margaret Fulton (1985) echoes Von Blum's point: "Research and publication as a precondition of promotion through our vertical rank structure has worked to replace the genuinely educated professor with the educational entrepreneur, the academic gamesperson" (p. 297). In less temperate language Charles J. Sykes (1988) unloads a mountain of detail in support of his contention that the research environment in the modern university is not only bad for teaching but actively hostile to it. And the Report of the Royal Commission on Post-Secondary Education in Nova Scotia (1985), among its many pertinent observations, calls attention to the fact that "in some departments, teaching and research....are regarded as antithetical...The Commission feels that universities will be doing a disservice to their students and the community if they continue to permit basic research and development to be emphasized at the expense of teaching and scholarship" (p. 75). The situation is grave enough to prompt even an ex-editor of PMLA to complain about "scholars who are frequently so narrow in their studies and specialized in their scholarship that they are simply incapable of teaching undergraduate introductory courses" (Schaefer, 1990, p.107).

Many analysts of post-secondary education, Kerr and Von Blum among them, have pointed out, too, how the demands of academic specialization have eroded the sense of the professors' responsibilities to the students, the department, and the university. For now the centres of the professor's working life are the journals in which his or her articles appear, the relatively small group of academics scattered across the continent who share the same often very narrow interests and an increasingly difficult and specialized language, and 
the conferences where they meet. These have become the most important realities of the professor's life, on which decisions about hiring, tenure, and promotion are based. As Cude (1988) observes, the professor's job is now a matter of "research opportunities" and "teaching loads" (p. 34). Officially, the university may worry about the quality of instruction and may in ringing policy statements endorse the importance of good teaching, but, in practice, the system rests very firmly on the central importance of research publication as the essential requirement. Those professors who do want to devote more time and energy to teaching, Peters and Mayfield (1982) suggest, have to participate in a system which induces "intellectual schizophrenia which encourages improvement in teaching but fails to reward it" (p. 105), a system which strongly resists any attempts to change things (Winkler, 1987).

In addition to the significant number of articles and books expressing personal dissatisfaction with the present emphasis on research, many empirical studies in the last twenty years indicate conclusively that the claims about the creative links between academic research, publication, and teaching have no basis in fact. Rushton, Murray, and Paunonen (1983) make the point unambiguously: "being good, bad, or indifferent at one activity [research] has very little implication for performance at the other [teaching]" (p. 113). Later studies by Feldman (1987) confirm the point: "an obvious interpretation of these results is either that, in general, the likelihood that research productivity actually benefits teaching is extremely small or that the two, for all practical purposes, are essentially unrelated" (p. 275). Summaries of research by Webster (1985) and later by Neill $(1985 ; 1989)$ stress the conclusion reached by every reliable study of this matter in the past thirty years: there is no evidence to support the view that academic research and publication have a beneficial effect upon instruction.

Now, there is an important and inescapable irony in all this. For those defending the orthodox university position on the important connections between research, publication, and teaching rest their case on the idea that a demonstrated and informed expertise guarantees intellectual and pedagogical excellence, since it requires a commitment to basing one's understanding and opinions on reliable and up-to-date empirical evidence. But the claim obviously displays no great familiarity with consistent research evidence, much of which has been available for years, and thus begins to appear as an article of faith, a reflex defence of the academic status quo, rather than as an informed conclusion based upon the best available results of creditable research. Even if one argues that the variables are very complex, especially in evaluations of the 
quality of instruction, and, therefore, that we need more detailed studies of this issue, that does not mean that we should therefore accept as true the confident assertions about the importance of research and publication for excellent instruction or that we must make that dubious principle the most important element in establishing appropriate workloads. In fact, the remarkable lack of evidence in support of that claim should encourage us to bring to it a very large degree of skepticism.

All of this is well known, and yet, except for the occasional exhortation that we should abandon the very narrow definition of research and publication and replace it with something a great deal more flexible, like service (Martin, 1977), scholarship (Royal Commission, 1985), vitality (Baldwin, 1990), or professional development (the expression common to colleges), the university professoriate in general continues vigorously to endorse the orthodox idea of an important interrelationship between research and teaching and to use it as the basic working principle in present decisions about hiring, tenure, and promotion, and in future planning. Indeed, the characteristic response in the universities to the growing crisis in undergraduate education stresses more than anything else the need for a more energetic recommitment (with more money and time) to research. Significantly, the CAUT position mentioned earlier about the fertile relationship between research and teaching was part of a plea for increased research funding.

A number of those who have examined this issue, Neill (1989) and Webster (1985) among others, have raised the obvious question: Why does the university cling to this idea in the face of so much evidence to the contrary? And the answer is clear enough: university professors have to believe that research has an integral connection with good teaching in order to justify to themselves and the public the structure of the workload. Only if we accept the fact that research and publication are a necessary part of excellent instruction can we then properly defend such a generous allocation of time and money for these activities to those responsible for teaching in institutions in which well over ninety percent of the full-time students are undergraduates (Education in Canada, 1989). For no matter how valuable some of the research endeavour in our universities may be, it is certainly not possible any longer (if it ever was) to defend the vast majority of research publications as important and original contributions to knowledge, so vital that we are willing increasingly to sacrifice the quality of the undergraduate programme in order to foster the activities which produce them.

The orthodox views about the importance of research and publication are so 
firmly entrenched in the university that no professor can afford to ignore them. We may have increasing doubts about the coherence and purpose of much what goes on in the university, but those inside commit their energies to publishing because that is the basic rule of the profession. We teach graduate students the principle, we hire and promote faculty on the basis of their research qualifications and activities, and we continue to fret about teaching, without doing very much to change the faculty's attitude to it (Botman and Gregor, 1984). The arduous apprenticeship, which requires years and years of faithful adherence to the central principle of the profession, weeds out many of those who find the order of priorities distasteful. In this connection, it is worth noting that the study by Rushton, Murray, and Paunonen (1983) indicated that the personality traits of teachers and of researchers appear to display "substantial heritabilities" (p. 112). In other words, the characteristics of these two types manifest themselves at an early age and endure. The researchers observed: "It is as likely that people selectively choose their academic niches as it is that they are shaped by them" (p. 112). So we should perhaps not be all that surprised to find that even rigorously trained academics, no matter what the evidence, accept as true those assumptions which have been the basis of their successful training and which have given them their coveted appointments. After all, to use a homely analogy, if we hire and promote major league hockey coaches solely on the basis of their knowledge of and their continuing research into the history of the game, the tensile properties of rubber, or the heat of fusion of arena ice, we can probably expect certain problems with the quality of the team play, but it is unlikely we will receive many official complaints from the coaches' union about the training, selection, and promotion of its members, especially when the coaches themselves have a monopoly on the education and hiring of new recruits to their ranks.

In the present climate of crisis in our universities, we hear many suggestions for reform. Nothing so far, however, has prompted any serious challenge from within to the central issue: the basic nature of the professor's work. Indeed, as the sense of trouble gets increasingly urgent, the pressure on faculty to conduct research intensifies, since now an important criterion in hiring and promotion is the amount of cash a professor brings along to fund a research team. The full-time faculty respond to the problems in the undergraduate curriculum by placing more and more of the responsibility for it in the hands of underpaid and overworked sessionals (Dassas, 1990) and by stressing the need for more research money. And the present odd tendency among many institutions, the University of Montreal, for example, to seek to transform themselves into 
upscale versions of the major research universities south of the border simply exacerbates the problems of teaching undergraduates properly.

If from within the universities the prospects for significant reforms of the professors' role are very dim, then our best hope for some challenge to the central faith in the importance of research and publishing rests on the creation of different institutions. The new undergraduate curriculums in the three British Columbia colleges, therefore, represent an important opportunity to develop degree-granting programmes in which excellent teaching is without reservation the most important responsibility of the faculty. If these colleges can maintain their commitment to that principle and not compromise it by importing the orthodox creed of the university professor, then these institutions may well initiate the most important reforms in post-secondary education in many decades.

That task will not, however, be easy. The sponsoring universities are keeping a very close watch on what is going on in these three colleges (naturally enough, since the universities will be granting the degrees), and already the pressure for conventional university qualification, workloads, and research activities is strong. Moreover, the significant increase in hiring is changing the nature of the college faculty and bringing more expectations for a conventional university working life, since many of the new instructors come directly from graduate school or from non-tenured university posts. So it remains to be seen whether or not these colleges will realize the important potential this opportunity provides.

One can only hope that those responsible for developing the college curriculum, the faculty workloads, and the contractual provisions for professional development will successfully resist those pressures to conform to the orthodox university ethic. If they contemplate the evidence more closely than their university colleagues and organize their work accordingly, they might just set an important example from which the rest of the country can really benefit. If they do not, then we shall have lost a very important chance to address the most significant factor in what is increasingly emerging as a major educational problem, the declining quality of our undergraduate programmes. 


\section{References}

Baldwin, Roger G. (1990). Faculty vitality beyond the research university: Extending a contextual concept. Journal of Higher Education, 61, 160-180.

Blum, Paul Von. (1986). Stillborn education: A critique of the American research university. Lanham, MD: University Press of America.

Botman, Elizabeth S., \& Gregor, Alexaner B. (1984). Faculty participation in teaching improvement programs. The Canadian Journal of Higher Education, 14, pp. 63-73.

Canadian Association of University Teachers. (1979). Handbook of policy statements, guidelines and model clauses. 3rd Edition. William Goede (Ed.). Ottawa, ONT: Canadian Association of University Teachers.

CAUT recommendations to the Government of Canada. (1987). CAUT Bulletin, 34, November, p. $2+$.

Cude, Wilfred. (1987). The Ph.D. trap. West Bay, Nova Scotia: Medicine Label Press.

Dassas, Véronique. (1990). The thorny problem of sessionals. CAUT Bulletin, 37, February, p. 11.

Feldman, Kenneth. (1987). Research productivity and scholarly accomplishment of college teachers as related to their instructional effectiveness: A review and exploration. Research in Higher Education, 26, 227-298.

Fulton, E. Margaret. (1985). Historical commitments in new times-teaching and research: Restructuring and reorientation. In The university into the 2lst century: An international conference on social and technological change (pp. 293-304). Victoria, BC: University of Victoria.

Jencks, Christopher \& Riesman, David. (1969). The academic revolution. Garden City, NJ: Doubleday.

Kerr, Clark. (1963). The uses of the university. Cambridge, MA: Harvard University Press, 1963.

MacLennan, Rod J., Gregson Evans, Joan, and Shaw, William S. (1985) Report of the Royal Commission on Post-Secondary Education.. Halifax: Nova Scotia.

Martin, Warren Bryan (Ed.). (1977). Redefining service, research, and teaching. New directions for higher education, no. 18. San Francisco, CA: Jossey-Bass.

Minister of Supply and Services. (1989). Education in Canada: A statistical review for 1987-1988. Ottawa, ONT.

Neill, S. D. (1985). Researcher/teacher: Is there a link? University of Western Ontario alumni gazette, (Winter) p. 32.

Neill, S. D. (1989). No significant relationship between research and teaching, research reveals. University affairs, 30, (April), p. 18.

Peters, Dianne S., \& Mayfield, J. Robert. (1982). Are there any rewards for teaching? Improving college \& university teaching, 30, 105-114.

Rushton, J. P., Murray, H. G., \& Paunonen, S. V. (1983). Personality, research creativity, and teaching effectiveness in university professors. Scientometrics, 5, 93-116.

Schaefer, William D. (1990). Without compromise: From chaos to coherence in higher education. San Francisco, CA: Jossey-Bass.

Sykes, Charles J. (1988). Profscam: Professors and the demise of higher education.. Washington, DC: Regnery Gateway.

Webster, David S. (1985). Does research productivity enhance teaching? Educational Record, 66 (Fall), pp. 60-62.

Winkler, Karen J. (1987). Interdisciplinary research: How big a challenge to traditional fields? Chronicle of higher education, 34, (October), pp. A1+. 